\title{
BREVE BIOGRAFIA DE MAURICE RONAI
}

\author{
WERTHER HOLZER ${ }^{1}$
}

Maurice Ronai, nascido em 1951 em Paris, graduado em História e Geografia, foi também aluno do Institut Des Hautes Études Cinématographiques, tendo realizado alguns filmes. Desde fevereiro de 2014 é membro da Commission Nationale de l'Informatique et dês Libertés - CNIL. Foi assistente de ensino superior da École dês Hautes Études en Sciences Sociales (EHESS), onde ministrou cursos sobre revoluções militares de 2006 a 2010, como membro do Grupo de Sociologia da Defesa fundado por Alain Joxe.

Membro do Partido Socialista Maurice criou, em 1998, a revista digital Temps Réels, órgão de comunicação oficial desse partido. Ingressou na vida pública em 1981, quando foi convidado a trabalhar no recém-criado Ministère de La Recherche dedicando-se, desde o início, ao tema dos sistemas de informações abertos. O coroamento dessa atuação foi a relatoria, em 2002, da publicação Administração eletrônica e proteção de dados pessoais, representando o Commissari at Général du Plan do Governo Francês. Deve ser destacada, nesta curta biografia, a vocação de Ronai como editor, redator e criador de periódicos científicos. Na década de 1980 foi redator de diversas publicações especializadas em tecnologia da informação: Vidéotex, Infotecture e Infotecture Europe. Colaborou e ainda colabora com publicações em diversos periódicos, com destaque para Le Monde Diplomatique. Criou com Jacques Rosselin, em 1990, o Courrier international.

A base desta formação transdisciplinar pode ser atribuída à criação do periódico Hérodote, em 1972, quando geógrafos e historiadores, entre eles Ronai, se agruparam em torno de Yves Lacoste a partir do lema "O raciocínio geográfico está ligado à ação". O primeiro número, editado em 1976, foi mal recebido tanto pela direita quanto pela esquerda, muito em função da retomada da discussão da Geopolítica. Os artigos Paysages (Hérodote [1], 1976, p. 125-159) e Paysages II, certamente são consequência direta de uma entrevista da qual fora encarregado Ronai, realizada em 1976 com um Foucault relutante em discutir conceitos

\footnotetext{
${ }^{1}$ Universidade Federal Fluminense.
} 
geográficos ${ }^{2}$. No entanto, a situação se reverte. A partir desta primeira entrevista Foucault dirige questões para os geógrafos da Hérodote, como acerca da constituição da Geografia enquanto ciência, a partir da discussão da estratégia e do exercício do poder. $\mathrm{O}$ artigo apresentado nesta tradução certamente reflete sobre tal temática.

\footnotetext{
${ }^{2}$ VUATTOUX, Arthur. Gouvernementalités contemporaines et territoires: une étude des usages géographiques de Michel Foucault. Memória de Pesquisa (Mestrado em Filosofia), Université Paris 1, 2010. Disponível em: <http://www.reseau-terra.eu/IMG/pdf/VUATTOUX_Arthur.pdf>.
} 